\title{
The Path of Brazilian Social Assistance Policy Post-1988: the Significance of Institutions and Ideas*
}

\author{
Natália Guimarães Duarte Sátyro \\ Universidade Federal de Minas Gerais, Brazil \\ Eleonora Schettini Martins Cunha \\ Universidade Federal de Minas Gerais, Brazil
}

This paper analyzes the construction of the social assistance policy at the federal level in Brazil over the last two decades. It focuses on the Federal Constitution of 1988 and subsequent infra-constitutional legislation, especially that enacted during the Fernando Henrique Cardoso (FHC) and Luiz Inácio Lula da Silva (Lula) administrations, which showed very different conceptions of social policy. For both administrations, we analyze the consequences of the institutional changes and legal framework introduced as well as the social policy ideas that informed them.

It is argued that the construction of social assistance in Brazil demanded much more than the constitutional provisions enacted in 1988. It included the entire set of subsequent constitutional legislation, a process in which the ruling party played a critical role. Categories of neo-institutionalism and the method of process tracing, plus in-depth interviews with relevant actors, were employed. Our findings point to the impact of the interaction between institutional structures, like constitutions and policy legacies, and the political projects of governing parties. Constitutional provisions, even if not bound to a policy, can prevent setbacks and anchor the action of pressure groups. They can also allow progressive administration to change the status quo.

Keywords: Social policies; assistance policy; institutional change; political party; policy legacy. 


\section{Introduction}

The 1988 Constitution's recognition of social assistance as a public policy and its inclusion in the Brazilian Social Welfare System ${ }^{1}$ makes that year a milestone from which this policy began to find its place in the Brazilian governmental decision-making arena. Given this context, studies on this policy became fertile ground for the understanding of a key issue in public policy analysis: the consolidation of a policy and the role of political and institutional factors in such process.

This article is a case study of the construction of the social assistance policy at the federal government level in Brazil over the last two decades. It focuses on the 1988 Federal Constitution and all infra-constitutional legislation produced in subsequent years, especially during the administrations of Presidents Fernando Henrique Cardoso - Brazilian Social Democracy Party (PSDB) - and Luiz Inácio Lula da Silva (Lula) - Workers' Party (PT). Both these administrations implemented institutional changes while presenting distinct conceptions of social policy. Our analysis depicts these changes and their impact for the building of the social assistance policy as well as the ideas and political projects that guided each administration initiatives.

The central argument is that the construction of social assistance as a public policy in Brazil demanded much more than the 1988 constitutional provisions. It required a subsequent infra-constitutional legislation to which the political project of the ruling party was also of great importance ${ }^{2}$. Hence, previous legal determinations operated as essential constraints (IMMERGUT, 1996; SKOCPOL, 1995) but the change in the image of social assistance in the political arena and in civil society was also a strong factor. This image was being prepared since the 1970s, in an incremental process which was influenced by the influence of formal and informal political actors and, in particular, by the role of presidents as representatives of specific political orientations.

The constitutional provisions and the institutional changes introduced by each administration constitute fertile soil for understanding the evolution of this policy. The changes can be understood mainly as the regulation of social assistance policy and the resulting functional reorganization of the State, which took place starting with the Constitution and more significantly during the Cardoso and Lula administrations.

1 In the 1988 Federal Constitution, Social Security (Seguridade Social) was defined as the system that encompasses three social policies: Social Security, Health and Social Assistance. In this paper we will translate this concept as "Social Welfare".

2 The Brazilian multiparty political system induces the formation of coalition governments for the formation of majorities. However, considering the leadership that the presidents' parties under analysis showed in the coalitions that were established, our position is that the political projects of their respective parties carried the greatest weight in determining the direction of social policies. 
This analysis of the construction of social assistance policy aims to identify the relationship between institutional structure and political action. Presidents are taken as references for the depiction of the conception of social policy that guided their administrations. According to Kingdon (2003), the president is the actor in the political system with the greatest ability to set policy priorities, as he has the prerogative to allocate institutional resources, to veto and to appoint key persons in the decision-making process. Furthermore, Kingdon highlights the president's capacity to manage "organizational resources" and "resources that command public attention." In addition, it is necessary to emphasize the political and social movements capacity to pressure as well as its alliances with parties on the left, as noted by the power resources theory (ESPING-ANDERSEN, 1990).

To this end, we use neo-institutional analytical categories that highlight the relevant determining factors in the explanation of public policy trajectory, as well as the role of ideas and values that legitimize some interests over others and guide institutional design (ESPING-ANDERSEN, 1990, 1999; OLSEN, 1997; SKOCPOL and AMENTA, 1986; SKOCPOL, 1995). Our thesis is that legal constraints affect the action of actors and the shaping of public policies. We agree with Immergut's view, which holds that "all these institutional norms determine distinct logics in decision making that define the parameters of government action and of the influence of interest groups" (IMMERGUT, 1996, p. 03). By setting different rules, institutions have the ability to facilitate or obstruct the action plans of stakeholders and of those involved in the decision-making arena. Moreover, the establishment of these rules is influenced by values and ideas defended and disseminated by certain agents.

We work with the hypothesis of the importance of the conception of social policies found in a governmental project for institutional choices, assuming that these choices are indicators of ideology. The classic hypothesis is that parties on the left of the ideological spectrum tend to invest more in social policies than parties on the right. Furthermore, the neo-institutional literature on Welfare State suggests that it is not only constitutional structures that establish constraints on the actions of policy-makers and affect the possibilities for action by authorities. State structures (HUBER, RAGIN and STEPHENS, 1993) and the rules of the game do the same thing (IMMERGUT, 1996). Huber et al (1993) suggest that state structures in particular act as contexts that differently constraint actors:

State structures serve as points of institutionalized veto against state welfare and are particularly constraining to leftist administrations. The existence of such veto points makes it difficult for leftist incumbents to implement generous and universalistic programs. In contrast, these veto points may have less effect on the policies of rightist administrations because the objective of such administrations is generally to preserve the status quo (HUBER, RAGIN and STEPHENS, 
1993, p. 745).

It is interesting to see how this proposition, which applies to countries with advanced economies, translates inversely to the Brazilian case, where the 1988 constitutional provisions became particularly constrictive for conservative governments ${ }^{3}$ that aimed at paradigmatic changes in the type of social protection offered. In the period being analyzed, unlike the countries to which Huber et al (1993) refers, institutional constraints facilitated the action of the left and made it difficult for those who sought to change the status quo toward less comprehensive patterns of protection.

Our analysis is also guided by the concept of reform used by Draibe (2003), which is restricted "to cases in which the changes affected the principles, structures, tough rules of a given policy" (DRAIBE, 2003, p. 67; free translation). The author divides the reforms' analytical time into two phases: "the introduction - referred or confined to changes in the legal framework, in the new rules definition and even the initial institutional changes - and the implementation - referred to the execution process previously decided and initiated." (DRAIBE, 2003; free translation).

To develop this analysis we used, basically, the techniques of process tracing, indepth interviews, as well as assumptions that it is possible to make inferences from descriptive analyses (KING, KEOHANE and VERBA, 1994, p. 34). Process tracing is suitable for analysis of inductive theories and hypotheses. Through case studies, the technique also makes it possible to construct relevant causal stories based on cause-and-effect relations (GEORGE and BENNET, 2005; MAHONEY, 2012). We carried out an analysis of the laws, governmental programs, programs of political parties and other documents produced by federal policy coordinators. We also held interviews with four technicians ${ }^{4}$

3 In general, the literature on parties seeks to identify them on an ideological spectrum ranging from the extreme right to the extreme left (LIMONGI and FIGUEIREDO, 1999; NICOLAU, 1998). In the Brazilian case, given the coalition governments, this classification (left and right) does not contribute to the present analysis, since the same coalition may contain parties in different positions along the left-right spectrum. In this study we therefore use the distinction between conservative and progressive governments, with reference to the ideas that guided them regarding proposed and implemented social policies. We understand that there were no substantive differences in economic policy between FHC and Lula, but there were differences in their social policies: these policies were more residual and showed compensatory characteristics in the Cardoso administration, while there were changes in coverage, total spending and the structuring of an institutionalized field of non-contributory policies by the Lula administration. We therefore consider the Lula administration more progressive.

4 The identities of the interviewees were preserved, being identified as 1, 2, 3 and 4. All are social workers with over 25 years of experience in the field of social work. Three were active at the municipal state and/or federal level and one at the federal level only. Their careers in the area began before the changes envisaged by the Constitution. The interviews were conducted in 2011, 
who worked in the federal government for both administrations and who personally accompanied the implementation of legal provisions.

The paper is organized into five sections. The first briefly analyzes the constitutional provisions as a structural element of the subsequent construction of the social assistance policy; the constitutional assembly was the moment used by stakeholders to introduce a first reform cycle. In the second section we analyze the emergence of a conservative agenda by actors aiming at reversing or blocking policy change when they noticed the importance of the institutional framework established by the 1988 Constitution. The Cardoso administrations are analyzed in the third section. There we suggest that even when complying with the legal provisions the absence of an orientation to defend the structuring of a national social assistance policy made these two presidential terms a period with no effective progress in building and consolidating this policy, despite the implementation of important aspects anticipated in the infra-constitutional regulation. In the fourth section, we show how a president who indeed placed social assistance in his political project brought in structural elements for implementing the policy at the national level. Lastly, we present some final considerations.

\section{The moment of introduction: the constitutional assembly}

The construction of the legitimacy of social assistance as a public policy could be seen during the administration of President José Sarney (member of the Brazilian Democratic Movement Party - PMDB) (1985 to 1990). Sarney recognized the existence of a "social debt" to the poorest strata of the population and considered this a pressing issue (MINISTÉRIO DAS RELAÇÕES EXTERIORES, 2008). Although this problem took on a public dimension only during this period, debates among specialists working in the social assistance area had been going on since the 1970s in the search for alternatives to the conservative ways of understanding and addressing the social issue.

The social policy issue had mobilized social workers during the II Brazilian Congress of Social Workers (1976) and the closing session of the III Congress (1979) was attended by the then labor leader Luiz Inácio da Silva. The event was strongly marked by the professional's option to align with the working class. Since then, groups of intellectuals and professionals organized around the idea of social assistance as a citizen's right, to be assured by the State, as opposed to the century-old practice of leaving to philanthropic institutions (especially religious organizations) the care for those who had no access to the necessary

during the Eighth National Conference on Social Assistance, in Brasilia, and had the objective of reconstructing the history of Social Assistance policy. They complement other interviews that have been conducted since 2005 with the same purpose. 
minimum social conditions for their survival ${ }^{5}$. Several academic and professional events were held during the following decade to address the issue, and spread the idea-force of social assistance as a right.

Here we highlight the importance of the political-institutional context of this brief but intense period that preceded the end of the military regime. During the 1970s semi-competitive legislative elections were held and the military opted for a gradual political liberalization as a way to weaken the opposition. There were only a pro-government party and a formal opposition party, respectively named National Renewal Alliance (ARENA) and Brazilian Democratic Movement (MDB). The dictatorial government suffered a significant defeat in the 1974 elections, when the MDB party won 59\% of the votes for the Senate and $48 \%$ of the House of Deputies, and elected the mayors of most of the major cities. This political setback forced the military government to re-establish the multiparty system in the country in 1979. This was followed by a rearrangement of the party system and the birth of PMDB, the Workers' Party (PT) and the Democratic Labor Party (PDT) (FLEURY, 1994; HAGGARD and KAUFMAN, 2008). In the 1980s, a slow and negotiated political opening process began, culminating in the election of the civilian Tancredo Neves as President of Brazil, in 1985.

In the second half of the 1980s there was, on the one hand, a new political scenario, with a new power distribution in which political actors were articulated in a new composition of the party system, with the comeback of an electoral arena as an important element of control and pressure of the political class. On the other hand, one could see social groups organized around the theme that were connected to members of the Executive and Legislative Branches and with the bureaucracy at the national level in order to produce changes in the way social problems should be treated. The creation of the Ministry of Housing and Social Welfare during the Sarney administration, which was later dismembered, and the creation of the Ministry of Social Security and Social Service (MPAS) with a Social Assistance Department were institutional changes that defined the locus in the federal administrative structure with specific jurisdiction for the area of social care (Interviewees 1 and 2).

The National Constitutional Assembly (ANC), first convened in 1986, was the arena where the first reforms in the area of social care occurred. Draibe called this moment the introduction (2003) when principles and rules were established to guide the changes. At this point political actors supported the idea of establishing social assistance as a

5 There is a vast literature which presents the characteristics that differentiate the Social Assistance organized on the basis of a conservative design from that guaranteed as a public policy, a duty of the State and the right of citizens. In this sense, we suggest the reading of Cardoso Júnior and Jaccoud (2005); Couto, Yasbeck, Silva and Raichelis (2011); Cunha (2013); Fagnani (2009); Sposati (2003a). 
citizen's right and the State's duty in providing it as public policy. As interviewees 2 and 3 reported, among the actors in the parliamentary arena at that time, Deputy Lúcia Vânia (PMDB later PSDB) stood out as a member of the Social Order Commission, who had a personal history in the area and would later, under Cardoso, assume the Department of Social Assistance. Alongside the Ministry of Social Security and Social Service (MPAS) created the Social Assistance Restructuring Commission comprised of technical experts. Another point to note is that the public policy community was comprised of a diverse set of social players including the LBA's Workers National Association (ANASSELBA), social worker's organizations, university professors (especially from the Catholic University of São Paulo), various professionals, members of numerous non-governmental organizations (PINHEIRO, 2008).

Skeptics may minimize the importance given to the National Constitutional Assembly, to the extent that it is a constitutive Lowian arena by nature and, therefore, is naturally like a window of opportunity for all possible reforms. However, we emphasize that not all possible or desirable reforms succeeded or were made possible at the time, as was the case of the land reform. From that point on, not only did social assistance enter the public agenda, but it was also instituted as a citizen's right, which significantly changed the conservative paradigm that had guided actions in this policy area until that point, having traditionally left them to philanthropy, charity and uncoordinated programs at various governmental levels. Since then, many authors have shown how the 1988 Federal Constitution was a milestone in the construction of social protection in Brazil. The beginning of the paradigm shift was thereby presented as the recognition of social assistance policy as part of social welfare together with social security and health (COUTO et al, 2011; CUNHA, 2013; IPEA, 2009; SÁTYRO, 2010). That is, at that time, there was a change in the principles that orient our object of analysis and that were achieved on the basis of subsequent regulations.

Among many paradigm changes brought about by the Constitution, Sátyro (2010) highlights those allowing the creation of legal redistributive mechanisms that tend to generate equality and create paths towards promoting national solidarity. This implied a different institutional design for social protection than previously existed, strongly based on the idea of social insurance, supported by contributions through work and formal employment. Since the 1930s, the social security system had been based on the nationalization of the pension system by President Getúlio Vargas (OLIVEIRA and TEIXEIRA, 1986) or, more specifically, since 1942 with the creation of the Brazilian Legion of Assistance (LBA). This setup was change at that moment by means of a shift from a Bismarckian paradigm to a Beveridgian one (BEVERIDGE REPORT, 1943) based on universal principles and social solidarity. There is no doubt that this step led to the overcoming of the 
previous social protection system based on contributions and merit, identified with the "regulated citizenship" concept (SANTOS, 1979) and made possible the construction of a new concept of citizenship.

Sátyro (2010), IPEA (2009), and Cardoso Jr and Jaccoud (2005) highlight these changes. First, it is noteworthy that in Chapter II, entitled "On Social Welfare," in Article 194, the Constitution states that by law, it is the government's duty to organize social welfare based on the following principles: "the universality of coverage and care," "the uniformity and equivalence of services and benefits for urban and rural populations," "the selectivity and distributiveness of benefits and services," "the irreducible value of benefits," "the equity in funding participation," "the diversity of the funding base," and the guarantee of a "democratic and decentralized administration." Articles 201 and 203 are added, concerning social security and social assistance, respectively, and state that no benefit payment may be below the minimum wage. This results in equal wage levels for men and women, persons from rural and urban areas, and, finally, to contributors and non-contributors. This, coupled with the principle of irreducibility, eliminates the possibility of mere symbolic value benefits as previously provided, thus minimizing their use for political patronage.

Second, the introduction of the right to access to services by populations that need them strengthens the idea of social assistance as a public policy and allows the development of a series of governmental initiatives. Hence, the institutional construction of this policy was reinforced.

Third, it is important to note that elderly and disabled persons in extreme poverty have the right to a solidarity income. The explicit recognition of this right is one of the highlights in the creation of a legal redistributive mechanism that tends to generate equality. It was based on this constitutional precept that the Continuous Cash Benefit (BPC) was created and it has become a major income transfer program. We also call attention to the recognition of the not entirely contributive retirement right to rural workers who live in regimes of family-based economies. As Sátyro (2010) points out, these are aspects that clearly place national solidarity as defining characteristics of social protection. A fifth important aspect was the linking of the benefit amount to the minimum wage, which took on even greater importance during the Lula administration, with an explicit policy of protection of minimum wage benefits.

Thus, a new social protection paradigm emerged guaranteed by the Constitution, which directly impacted the construction of new social agendas, since it established rights, principles and provisions that directly affect governmental action. In the implementation that then took place the constitutional protection produced a profound change in policy conception, supply conditions, institutional organization and coverage. This step was 
essential in the long, still ongoing, process of establishing social rights in the institutional and legal framework of the Brazilian State, with real consequences in the government's role of ensuring these rights through public policy.

The changes that shaped this constitutive arena (LOWI, 1964, 1972) led to intense institutional movements, much discussion and intense mobilization, including the approval of important laws in the 1990s. This implies, as Draibe (2003) suggests, that during this period we can identify the introduction of reforms, since changes were made in legal principles and rules. But the effective implementation of social assistance policy according to the new legal frameworks occurred only in the 2000s. This long period for the implementation of the changes in social assistance was different from the changes made to health policy (MENICUCCI, 2007), another component of the Brazilian Social Welfare in which social assistance policy-makers sought inspiration.

\section{9-1993: a conservative agenda}

With the enactment of the 1988 Constitution, there was a change in the setting and locus of the decision-making arena. At that moment decisions left the congressional arena and migrated mostly to the executive arena, which in this moment consisted of administrations with significantly conservative profiles. This allows one to see the importance of the basic framework set in the Constitution in order to protect the social assistance policy from more conservative moves. Constitutional constraints, in neo-institutionalist language, may not necessarily oblige action, but they constrain the attempts at backlashes at processes that have moved ahead.

Initially, certain important aspects of the period from 1989 to 1993 should be noted. The enactment of the Federal Constitution showed that there was a need for further legislation to regulate various articles, including those regarding social assistance, since the Constitution itself determined that the transitional provisions on Social Welfare should be regulated within a maximum of twelve month's time. The following year, still during Sarney's administration, the first legislative elections were held for the federal level, and enacting this new legislation became the job of the newly elected Congress. In the executive area, Fernando Collor de Melo, a member of National Renovation Party (PRN), was elected president of Brazil, with a conservative discourse on social care, and imposed restrictive economic measures, which directly affected the quality of life of the workers. He created the Ministry of Social Action, led by Margarida Procópio, a technician by career and leader of the LBA in Alagoas, the president's home state (Interviewees 2 and 3). In this scenario, the Institute of Applied Economic Research (IPEA) created a commission to effect the project of the Organic Law on Social Assistance. Professors at the University 
of Brasília also articulated with the same objective. Other representative organisms of social workers also became involved, such as ANASSELBA, the Local and State Managers National Front, Persons with Disabilities, Senior Citizens, Children and Adolescents, and researchers with rights movements from several universities. They organized events to collect subsidies for drawing up the organic law and pressured political actors to regulate social assistance (SPOSATI, 2003b).

Meanwhile, Deputy Raimundo Bezerra (PMDB) proposed Congressional Bill No. 3.099/89, which legislated on social assistance. After approval in the House of Deputies in July 1989, the project was approved by the Senate in May 1990. However, in September the law was entirely vetoed by President Collor, who claimed the bill had been inadequate since its inception. A new initiative from the Legislative Branch, by Congressman Alckmim Filho (PSDB) and Reditário Cassol (then in PTB) in April 1991, resubmitted the Bill with minor changes (MINISTÉRIO PÚBLICO DO ESTADO DO ESPÍRITO SANTO, 2000). That year, professionals from the area held the $1^{\text {st }}$ National Seminar on Social Assistance, in Brasilia, which gave rise to a "Commission for Organic Law on Social Assistance." There they wrote a document entitled "Viewpoint that we support." This document was used by Deputy Eduardo Jorge (PT) and others, who submitted Congressional Bill No. 3154-91, with Deputy Fátima Pelaes (PSDB) as the rapporteur, and was widely discussed with society at seminars across the country jointly promoted by the Ministry of Social Welfare LBA, SESC and SESI. Congressmen from civil society organizations, Legislative Branch, FLBA workers and leaders, members of the Congressional Commission on Social Security and Family, Movement for Ethics in Politics, Brazilian Association of Non-Governmental Organizations (ABONG) and the National Food Security Council participated in the seminars. This intense mobilization culminated in the National Conference on Social Assistance in June 1993 (Interviewees 3 and 4).

In mid-1993, during President Itamar Franco's administration (PMDB), with Jutahy Magalhães Júnior (PSDB) as Minister of Social Welfare, there was a position from the Executive Branch of Government against the project, which had been under discussion by social and political actors involved in the movement in favor of the Organic Law on Social Assistance (LOAS). A different proposal for regulation had been drawn up that was fundamentally contrary to the expectations of these actors. At that conference, under the leadership of then councilwoman for the city of São Paulo, Aldaíza Sposati (PT), a specialist in the area, a stand against the project of the organizers arose. The main items of Bill No. 3154, analyzed point by point by the members of the conference, were agreed upon by acclamation. The organizers upheld the results and submitted the bill to the National Council on Social Assistance, which approved it, but with restrictions proposed by the Finance Ministry in order to avoid a negative impact on the government budget. 
The Ministry of Social Welfare presented the bill to President Itamar in July 1993, who sent it to Congress. With the support of Congressman Fátima Pelaes, the bill was approved by Congress in September and signed into law by the president in December of that year. The Organic Law on Social Assistance was born at that point, even if by forceps (MINISTÉRIO PÚBLICO DO ESTADO DO ESPÍRITO SANTO, 2000; Interviews 1, 2 and 3).

What is clear from this brief history is that the construction of the Organic Law on Social Assistance was a much more lengthy and polemic process than the inclusion of the right in the Constitutional Assembly, as it took five years to be approved. The disputes took place among political and social groups in the legislative and executive arenas, especially the former, given the issue's legislative character and the fact that Congress was more favorable to regulation. In this process, the relationship among players from Congress, from the bureaucratic structure and from society was crucial to achieve the necessary social support to approve the Organic Social Assistance law. The democratic environment based on universal suffrage and multiparty system allows for real pressure from social and political organized groups creating constraints to state intervention, in this case, the state veto (ESPING-ANDERSEN, 1990; KORPI, 1983). Constitutional provisions were regulated, on the one hand, according to the power pressure of these groups and, on the other, to the obligations imposed by the Constitution itself and subsequent regulations in this specific area. We understand that changes in the rules of the game allowed the social assistance policy community (KINGDON, 2003), then a minority, to pressure the government to regulate what was determined by the constitution. The rules undermined the ability of the majority in the bureaucratic apparatus and government to block such innovations in the Brazilian social protection policy, barring any reversion to the previous model ${ }^{6}$.

However, despite all conservative approaches, the overall outcome was positive, as the Organic Law on Social Assistance was approved in 1993. An important aspect of this law is that it consolidates a decentralized and participatory policy which is constituted in the three spheres of government, by administrative agencies and deliberative institutions of a collegial character with a single command per government level. It establishes instruments for planning, management, finance and social control at national, state and municipal levels.

6 If we make a brief comparison between the time-length and processes of social assistance and health care construction we see that social assistance, despite having constitutional status was considered less legitimate than health care. If the efforts at structuring health stalled its implementation (MENICUCCI, 2007), in social assistance, structuring processes greatly slowed down its effective entry in the decision-making process. In 1990, two years after the 1988 Federal Constitution approval, the Organic Law on Health (LOS) was enacted (Law 8080 of September, 1990 and Law 8142 of December, 1990). 
Another determination in the Organic Law on Social Assistance was the provision that assistance is a State's responsibility in partnership with civil society organizations. Here one can see the importance of the legacy of earlier policies. Since the colonial period social assistance had been provided social organizations with little investment by the State, which had insufficient equipment and human resources to take the responsibility for guaranteeing rights (CUNHA, 2013). Therefore, the Organic Law on Social Assistance points to a necessary institutional reorganization that enabled its implementation, which depended on subsequent governments.

\section{Cardoso administrations: two terms, two positions}

The entire legal process in the first half of the 1990s was an important step toward the consolidation of social protection in Brazil, particularly of the social assistance policy. However, the institutional evolution since the 1988 Constitution was marked by sharp discontinuities. Clearly, it was a process that qualified the public sector on the one hand, and political decisions on the other. In each administration during that decade one could see the institutional fragility marked by the setting up and dismantling of institutions.

In his plan of government submitted as presidential candidate in 1994 (CARDOSO, 1994), Fernando Henrique Cardoso recognized the Brazilian social debt and proposed a new model of development as an alternative to right this debt, supported by investments in health, education, sanitation, housing and security. His plan proposed the Community Solidarity Program as articulator of emergency actions and reforms in these areas and called for partnerships between the state, philanthropic institutions and community associations as the best strategy for this type of action. Therefore, two guidelines stand out: the guarantee that social policies should give priority to areas of chronic poverty and the understanding that the most important role is in society and not the state as guarantor of protection. It mentions social protection when it comes to social security, identifying it as one of its central aspects. Specifically with regard to social assistance, it only offers goals and objectives for specific segments, such as children, the elderly and persons with disabilities.

On his first day in office, Cardoso issued Provisional Measure 813/95, which rearranged the social assistance area. He extinguished the Ministry of Social Welfare, the National Council for Food and Nutrition Security (Consea), the Brazilian Legion of Assistance (LBA) and the Brazilian Center for Childhood and Adolescence (CBIA). At the same time, he created the Ministry of Social Security and Social Service (MPAS), with a Department of Social Assistance, headed by Deputy Lucia Vânia (PSDB) who had served on the Social Order Commission of the Constitutional Assembly. The National Council 
on Social Assistance (CNAS), which had been created during Itamar Franco's previous government, was subordinated to the Department of Social Assistance (Interviewees 1, 3 and 4).

President Cardoso also created the Solidarity Community Program and the Council of the Solidarity Community Program to replace the National Council for Food and Nutrition Security (Consea), which coordinated the Plan to Fight Hunger and Poverty for Life (PCFM). This program initially incorporated the Emergency Food Distribution Program (PRODEA, also known as Basic Agenda) which was later extinguished. The Solidarity Community Program worked with an agenda of its own, defined by the president and the first lady, Ruth Cardoso, and was aimed at combating poverty and social exclusion through the mobilization of public resources and society, focusing on transferring tasks from the public to the private sector (TESSAROLO and KROHLING, 2011). There was obvious competition for responsibility and institutional overlap between the Program and Department of Social Assistance/Ministry of Social Security and Social Service (MPAS), clearly evidencing that the presidential agenda was centered on the former, disqualifying the institutionalization process initiated at the ministerial level. It can be inferred that the issue of combating poverty, even though part of the political project, took its own course, channeling budgetary resources earmarked for the Solidarity Community Program ${ }^{7}$.

Thus, the Cardoso government was characterized by the State's ambiguity in its role in social assistance policy, mainly as regards the federal government scope. Still, Department of Social Assistance/Ministry of Social Security and Social Service (MPAS) produced the First Basic Operational Norm (NOB), the National Social Assistance Policy (PNAS-19988; 2001) and Basic Operational Norm/02 ${ }^{9}$. Moreover, the Continuous Cash Benefit (BPC) program, as anticipated in the Organic Law on Social Assistance, was regulated (1996) and implemented (1997), with a more restrictive interpretation than that

7 According to Valente, when Cardoso suspended Basic Agenda, which was the articulation and focus of governmental actions at the municipal level, he left about ten million people without access to food allotments. Exemplary action of treatment by this administration was the suspension of international tenders for the purchase of iodate used to fortify salt and to prevent a number of diseases and disorders related to iodine deficiency (VALENTE, 2004). During a period of over two years, not only this, but other programs were suspended, meaning a break with a long period of evolution, since organizations caring for the elderly, persons with disabilities and children had their resources cut off abruptly. According to Valente, the extinction of these programs was "part of compliance with the standards required by international agreements that established the suspension of policies of building up inventories and reducing spending on social programs of a more universal character" (VALENTE, 2004).

8 This National Social Assistance Policy is rarely reported in the literature. For more, see (ALCHORNE, 2013).

9 Basic Operational Norm approved by Resolution No. 204/CNAS of December 4th, 1997 and Basic Operational Norm 2 approved by Resolution No. 207/CNAS of December 16th, 1998. 
provided in the Law for disabled persons and their families, reaching $346,219^{10}$ beneficiaries during its first year.

The normative instruments produced during that period became regulatory efforts to make it feasible to implant the Organic Law on Social Assistance. However, despite the apparent volume, these instruments were timid in their proposals, with some exceptions. The main contributions of the National Social Assistance Policy (1998) were toward establishing roles for social assistance (still aimed at social integration, which kept the focus on individuals and/or social groups), the organization of the management, and the designation of more detailed competencies for each level of government. But, in general, this regulation is considered insignificant by the social assistance policy community (Interviewees 2, 3 and 4).

Basic Operational Norm/02 brought more significant contributions by better defining manager's roles at each level of government and instituting automatic transfer of resources among levels of government, through the Social Assistance Fund, based on criteria that took into consideration social indicators, giving the states and municipalities autonomy to manage them. Even so, the "historical series" were retained in order to ensure funding to private institutions, as they were already maintained by federal resources, showing the importance of legacies from earlier policies. Another important innovation was the creation of bipartite interagency commissions in each state and the Tripartite Interagency Commission at the national level, instances with the mission of negotiating on the management system, respecting the state's autonomy (Ministry of Social Development, Basic Operational Norm/02).

The state and municipal processes effectively begin during this period, but direct transfers were replaced with agreements signed between public administration managers and the Federal Savings Bank (Caixa Econômica Federal) (Interviewees 1 e 2). Even with some innovative content, these norms did not lead to the implementation reforms (DRAIBE, 2003) that would significantly alter the structure of the Social Assistance Policy System. Efforts at regulation, which can be attributed to the presence of political community members in the Ministry staff, failed to affect the implementation process because they were not in line with government priorities.

When applying for reelection, Fernando Henrique Cardoso presented a (Avança, 1998) program in which he reiterated his intention to fight poverty with actions focused on critical areas through partnerships between the State and civil society. This program expanded the range of actions of the Community Solidarity Program by changing its main

10 This data was extracted from the MDS website. Figure: "Evolução da concessão e dos gastos com o BPC - LOAS no período de 1996 a 2001," Issued between 1996 and 2001. Link: http:// www.mds.gov.br/relcrys/bpc/1_tab_evolucao_concessao.htm 
strategy to support local development. It also highlighted the role of the Council for Community Solidarity, understood as the space for political dialogue between government and society, where the council would develop a "Basic social agenda" for the country. His position was that the combined cash transfer programs constituted a system of social protection that was fundamental to the strategy to fight against hunger and poverty. When dealing specifically with social assistance, Cardoso enhanced the selectivity and focus of actions, with special attention to population groups including those in extreme poverty.

During Cardoso's second administration, the most representative action of institutional strengthening was the conversion of the Department of Social Assistance (Secretaria de Assistência Social - into the State Department of Social Assistance (Secretaria de Estado de Assistência Social - SEAS), giving it status as a Ministry. Heading this department was Wanda Engel Aduan, indicated by the Liberal Front Party (PFL, now named Democratas). It was a period of stagnation of the ongoing process and reflected the political and ideological debate in the political arena. On one side there were proponents of the new social protection paradigm, in other words, defendants of the Constitution itself; on the other, there were neoliberals advocating a leaner State, although contrary to the provisions of the 1988 Constitution. It was a period characterized by attempts at opening up national solidarity principles in order to redirect policies and State accountability and ensure social minimums (BOSCHETTI, 2006). Although Cardoso was considered to be from a center-left party, he made the clear choice for structural adjustments that, in practice, minimized actions geared toward social assistance through income transfer in various areas of public policies ${ }^{11}$. According to Dye (2003), considering that public policy is "whatever the government chooses to do or not to do," a concept based on the premise that a choice indicates the top authority's preferences, Cardoso's choice was for fiscal adjustment rather than for social protection as the trademark of social assistance policy.

In the absence of a strong action by the federal government, this was a period when municipal actions expressed the need for policies for social care. During the second half of the 1990s, several municipalities created income-based cash transfer programs, especially Brasília, Campinas and Ribeirão Preto. The Brasilia program received the broadest

11 It was a period of isolated actions carried out by different ministries and public agencies, focusing on income transfer programs and food distribution. In 2001, the Scholarship Program (Bolsa Escola) by the Ministry of Education, and Food Grants (Bolsa-Alimentação) were set up by the Ministry of Health, this latter program meaning the conversion of the former Institute to Fight Malnutrition (ICCN) into a National Minimum Income Program linked to health. In 2002, the Cooking Gas Allowance (Auxílio-Gás) was put into operation by the Ministry of Mines and Energy. In 2002, the Scholarship Program reached 5.1 million beneficiaries and the Food Grants and the Cooking Gas Allowance reached 8.5 million. Benefits could overlap, a fact that led to the need for Unified Registration Files in the attempt to control the program's coverage and results (IPEA, 2009, p. 214). 
funding and marketing ${ }^{12}$ and served as a reference for initiatives taken later by the Cardoso administration. These experiences expressed an issue that had been gaining solidity, especially in the assistance policy community: the need for federal income transfer programs that could produce broader redistributive effects (SPOSATI, 1996; NÚCLEO DE SEGURIDADE E ASSISTÊNCIA SOCIAL, 1996). Even though consensus was not reached, the idea took on greater importance during the Lula government ${ }^{13}$.

Our analysis shares with Draibe (1998a) the perception that the reform instituted in social assistance policy by the Federal Constitution and by the Organic Law on Social Assistance found neither acceptance or encouragement from the State during either of the Cardoso administrations, in the sense of there having been any radical change, in Olsen's $(1997)^{14}$ terms. None of the innovations were implemented or made routine operations . What happened was an incremental process, both in the recognition of issues as problems to be addressed by social assistance, and in the setting up of an administrative or bureaucratic system to uphold these policies. In other words, no institutional foundations were set down to implement any social assistance policies. However, some linear and incremental changes were processed, but they cannot be considered as implementation of a reform that radically altered the policy. That is, Cardoso's actions from the point of view of social assistance remained a fragmented set of actions and programs working from a perspective of residual protection and provision of minimum social standards that had little to do with the provisions of the 1988 Constitution.

12 Besides these three, many other municipal governments also adopted some type of transfer program, including Belém, Belo Horizonte, Boa Vista, Catanduva, Ferraz de Vasconcellos, Franca, Guaratinguetá, Guariba, Goiânia, Jaboticabal, Jundiaí, Mundo Novo, Limeira, Osasco, Ourinhos, Paracatu, Piracicaba, Presidente Prudente, Santo André, São Francisco do Conde, São José do Conde, São José dos Campos, São Luiz, Tocantins and Vitória (LAVINAS, 1998; NÚCLEO DE SEGURIDADE E ASSISTÊNCIA SOCIAL, 1996).

13 The debate in the assistance policy community encompassed two basic sides. On the one hand, there was a focus on the economic aspects of this type of program, with the argument that it would reduce the solution of inequality to the monetary aspect of social differences. Some used this argument to reject the strategy. On the other hand, among those who accepted the idea, the debate revolved mainly around the scope of the program - whether it should be universal or focused - and the establishment of conditions to be set down for persons to have access to it (SPOSATI, 1996; NÚCLEO DE SEGURIDADE E ASSISTÊNCIA SOCIAL, 1996).

14 Olsen (1997) considers that institutional changes are revolutionary when they occur quickly and significantly, and thus alter the social order. They are radical when they occur quickly and significantly, altering governance but not the social order. And they are incremental when they occur slowly and gradually, with long-term consequences. 


\section{The Lula administrations: two terms, one attitude}

Poverty and hunger were issues strongly debated in the academy and public administration when Lula's government began. Federal, state and local programs all around the country were targeted at poor households, although based on different poverty lines but all recognizing poverty as a social risk. On the other hand, social assistance was part of the political project of the new president's party, the Worker's Party (PT, Partido dos Trabalhadores), which had been slowly built up through government programs formulated to compete in presidential elections since $1989^{15}$.

PT's plan for government for the 1989 campaign included the commitment to meet the "basic requirements of large marginalized sectors" of the population and the proposal to improve income distribution, without specifically mentioning social assistance. The 1994 government program has its central goal "to fight poverty and destitution which affects half of the Brazilian population" stating that all objectives should be subjected to that goal. The planned actions were presented by segment (persons with disabilities, children and adolescents, the elderly), following the way social assistance was organized at the time but defining that "social assistance policy, limiting its scope, should give attention to children and adolescents in personal and social risk, and to persons and groups who are in vulnerable situations". In its 1998 program PT expressed the intention to adopt minimum income programs as well as to face "the serious problem of hunger". Thus, it proposed to extend the School Grants (Bolsas-Escola), "progressively implement the Minimum Income Program for low-income Brazilians who do not benefit from other programs," and set up a program to fight hunger (MINISTÉRIO DO PLANEJAMENTO, ORÇAMENTO E GESTÃO, 2003).

The 2002 government program specifically refers to the social assistance policy, seeing it as part of a set of social policies that should promote social inclusion in an articulated way. It assumed criticisms made by the policy community regarding the fragmented, focused and overlapping aspects of previous programs. The new program proposed a revision of the various existing income transfer programs by rationalizing governmental action and reaching potential users not yet included. It reaffirmed the universal and public conception of social assistance policy, as anticipated in its legal framework. It was also committed to the implementation of the Zero Hunger Program (Programa Fome Zero), to eradicate extreme poverty and hunger. The "Brazil for Everyone Plan: participation and inclusion (Plano Brasil de Todos: participação e inclusão)" is a strategic document that indicated the Lula governmental orientation, with the clear intention of confronting

15 For more details see: http://www.fpabramo.org.br. 
problems considered fundamental, including the concentration of income and wealth, and social exclusion (Programas, undated).

The first year of his first term was marked by a lack of clarity in institutional guidelines. Lula dismembered the Ministry of Social Security and Social Service (MPAS) (created by Cardoso) and created the Ministry of Social Assistance (MAS) and appointed Benedita da Silva (PT) as minister, and the Special Ministry for Food Security and Fight Against Hunger (MESA) ${ }^{16}$ headed by José Graziano da Silva (PT), who was responsible for the Zero Hunger Program. Consea, previously extinguished by Cardoso, was also reconstituted. However, according to all interviewees, this institutional arrangement received strong criticism from the social assistance policy community, not only because it reproduced a restrictive way of conceiving social policy, but also because it maintained the earlier program's overlapping and fragmentation. It also disregarded the single command guideline for actions aimed at social protection recommended by the Organic Law on Social Assistance. Very sharp criticisms were also made specifically to the Zero Hunger Program, regarding the lack of structure and clarity in its strategies beyond those that were in clear disparity with the nature of the program by an ideological issue. Moreover, according to Almeida (2004), the Program showed lacunas in its implementation, especially due to problems with inter-ministerial coordination.

A year later, through Provisional Measure No. 163/2004, the Ministry of Social Development and Combat Against Hunger (MDS) was created and became responsible for social assistance policies, food security and nutrition, and income transfer, unifying the two ministries created a year earlier (Ministry of Social Assistance (MAS) and Special Ministry for Food Security and Fight Against Hunger (MESA). Heading it was Minister Patrus Ananias (PT).

The lack of coordination observed at the beginning was replaced by a new rearrangement of actors in the political arena. The party that had long been opposition was learning how to govern and impose its governance projects, while the long-time situation groups were learning how to be opposition. There was an unprecedented political context

16 The Special Ministry for Food Security and Fight Against Hunger (MESA) was responsible for structuring and implementing the Zero Hunger Program the first initiative of the new government to coordinate actions to fight hunger, malnutrition, and extreme poverty by promoting food and nutritional security. The program gave greater public visibility to the government's social agenda and, at the same time, had the merit of returning obligations in this area to the State, which had been diluted into organizations of civil society in the previous administration through the Community Solidarity Program, which financed them. However, the expected applause was not forthcoming. The program came under heavy fire from experts on the conception and the strategies used and it resulted in failure. A year after being launched, it was abandoned as the government's main action, but its space was quickly occupied by the Family Support Program (Programa Bolsa Família). 
in Brazil in which social and political groups who had long been external actors in decision-making were now able to directly pressure and act within the government. Not only was the president's party importance and influence in defining the presidential agenda reinforced, but the ability of organized groups to pressure also became much greater.

At this point it is important to call attention to the central role of Minister Patrus Ananias de Sousa as Minister of Social Development and Combat against Hunger (MDS) in the executive arena. This is a relevant factor, since individuals who occupy the upper levels of bureaucracies as ministers and ministerial executive secretaries not only can reorient the priorities of the government agenda, but also pay attention to and observe previously existing issues (EVANS, RUESCHEMEYER and SKOCPOL, 1985; KINGDON, 2003). This minister, who had been mayor of Belo Horizonte, where he implemented significant reforms in the social welfare policy, firmly stated his commitment to the presidential political project, and organized the Ministry by appointing experts in the area to the top board and to the upper levels of the bureaucracy, all being persons with recognized expertise, some of them having been active in this field since the formulation of the pertinent articles in the constitution and in the Organic Law on Social Assistance as well as they were active militants of the Social Assistance Movement (Interviewees 2, 3 and 4).

The new political context with a progressive administration having reached the federal government proved extremely favorable for the implementation of reforms that, according to Draibe (2003), would give continuity to the introductory reform expressed in the Federal Constitution and the Organic Law on Social Assistance. Lula's political project for social assistance included three dimensions: the regulation of social assistance, the construction of the administrative apparatus, and an institutional framework for providing social care services and income transfers. In the first dimension, in 2003, the Fourth National Conference on Social Assistance was held, and called for the immediate implementation of the Unified Social Assistance System. The decision found positive and converging resonance in the Ministry, initiating efforts to regulate the system, which occurred the following year, with the approval of the National Social Assistance Policy (PNAS-2004) by CNAS. The policy was widely discussed across the country with congress members, other levels of government and other political actors, such as managers, representatives of non-governmental organizations, social movements, experts, forming a broad coalition of support for its development and implementation (Interviewees 1, 2 and 3).

The National Social Assistance Policy (PNAS-2004) can be considered a new regulatory framework for social assistance. One major change was the shift in the logic of protection. Social assistance had previously been focused on "target groups," in different segments considered vulnerable, but the focus was redirected to ensure "securities" (security of acceptance, of coexistence, of development, of autonomy, of circumstantial risk 
survival, of income). Together, they aimed to protect people unable to provide basic needs for themselves such as food and shelter, those without family and incapable of providing themselves with a safe and independent life, people who suffer the consequences of loss of family or job, who are in situations of isolation, and also to protect those who do not have sufficient cash funds to ensure their own survival and that of their families (income security), including the elderly, the unemployed, the disabled and those in large families (IPEA, 2007, 2009; MINISTÉRIO DO DESENVOLVIMENTO SOCIAL E DO COMBATE À FOME, 2004).

This conceptual shift clearly introduces the idea of social protection detached from any specific target audience including removing the focus from the poorest or the unemployed segments. The National Social Assistance Policy stated that social protection should be provided to all those living in insecure social conditions, regardless of their social group, but rather based on their level of exposure to risk. This policy takes a real step in constructing a Marshallian notion of citizenship as a person belonging to the national community, regardless of age, population segment, or income.

The National Social Assistance Policy reinforced the guidelines found in the Organic Law on Social Assistance for political and administrative decentralization, with greater interaction among the three spheres of government. It emphasized the primacy of State responsibility at every level of government, and highlighted the idea of popular participation through representative organizations both in the formulation process and in social control. It also reinforced the process of negotiation and agreement of the Interagency Commissions and highlights the role of Social Assistance Forums as instances of participation by civil society (MINISTÉRIO DO DESENVOLVIMENTO SOCIAL E DO COMBATE À FOME, 2004).

As a result of the National Social Assistance Policy -2004, one year later the Basic Operational Norm of the Unified Social Assistance System (NOB-PNAS ${ }^{17}$ was approved by CNAS. It consolidated important changes in social care services. The Basic Operational Norm-Unified Social Assistance System presented important advances compared to previous Basic Operational Norms. It organized, in a clear and detailed way, the two planned levels of social protection provided in National Social Assistance Policy - basic and special - that structured how social assistance services would be provided. The definition of services that are specific to this policy area, not only give it its own identity. It also guided providers of public and private services as to the actions for each type of security and how they should be offered.

17 Basic Operational Norm 3, known as Basic Operational Norm-Unified Social Assistance System, was approved by Resolution No. 27/CNAS, of February 24 $4^{\text {th }}, 2005$. 
The new social assistance regulatory framework significantly altered social assistance and referred to the necessary institutional reorganization, at all government levels, not only in organizational structures, but also the provision of services ${ }^{18}$, the articulation and coordination of actions (public and private) in the form of funding, training and recruitment of human resources, among many other aspects, which constituted the second component of the government's agenda. The Basic Operational Norms of the Unified Social Assistance System established the minimum level of spending related to the two levels of social protection, with criteria for distributing resources that guaranteed automatic transfer of federal funds to states and municipalities. This change was substantial because it disconnected them from agreements. The newer system also promoted greater municipal autonomy for allocating federal funds. It became clear that one of the main goals of this third Basic Operational Norm was to transform the social assistance policy into a truly federal policy through the effective cooperation among the Federal Government, States, Federal District and municipalities. Thus the process of negotiation carried out at Tripartite Intermanager Commission (CIT) became extremely important since the complexity of the changes would affect all levels of government in Brazil. This process radically changed the effectiveness of the provisions of the Organic Law on Social Assistance, which had remained virtually inert during the Cardoso administrations, whose agenda gave priority to the Solidarity Community Program.

The third flank of the Lula administration was income transfer. Already in October 2003, other four previously created programs ${ }^{19}$ were added to the Family Support Program (Programa Bolsa Família), making it the largest conditioned income transfer program in Brazilian and world history. An important aspect is that the four previous programs were not articulated among one another, each one having its own executive agency, overlapping objectives and target audience, with separate information systems that did not communicate. This allowed one family to receive all four benefits while others would receive none, even with the same conditions of eligibility. None of these programs was intended to become universal, nor was any of them nationwide. The sizes of benefits and inclusion

18 The National Social Assistance Policy sets the groundwork for the consolidation of social care services by reaffirming the public responsibility in providing these services and confirming the new role of the State in this area, providing for the integration of private organizations as co-participants, reaffirming the propositions in Organic Law on Social Assistance. Finally, an important step standardized the protections provided under its responsibility and establishes them not only by territory but also by complexity (MINISTÉRIO DO DESENVOLVIMENTO SOCIAL E DO COMBATE À FOME, 2004).

19 The Family Support Program (Programa Bolsa Família) is the combination of the Scholarship Program (Bolsa Escola), Food Grants (Bolsa Alimentação) and Cooking Gas Allowance (Auxílio-Gás), Programs created in 2001 and 2002 during the Cardoso administration. Food-cards (Cartão-Alimentação) were created seven months later by the Lula administration. 
criteria differ among programs, so the federal government was making different transfers to families in similar situations, justifying them with virtually the same arguments. By controlling overlapping of beneficiaries and applying the eligibility criteria, the Family Support Program went into existence benefiting 3,615,596 families, with average benefits being higher than the previous ones (IPEA, 2007).

Therefore, the change in the structuring of the social assistance policy is evident, as described by Sátyro (2010). Until the early 2000s the government's participation in providing social care services was limited to financing the Continuing Action Services (SAC) offered by states, municipalities or nonprofit organizations with historical links with the Ministry. The program was structured according to target audiences, especially persons with disabilities, the elderly, children and adolescents, through agreements with local governments, which monitored and inspected the service providing organizations. This structure was changed by the Lula administration.

In summary, at the first stage two important regulatory milestones were established: the National Social Assistance Policy-2004 and the Basic Operational Norm-Unified Social Assistance System-2005, which allowed the system to be structured, and the strengthening of income transfers aimed at universal coverage for its target population. A second stage was the actual implementation of the social care service system, which ensured protection and guaranteed security. Finally, a conditional cash transfer program was implemented with a universalizing logic. It reached very significant numbers of persons.

The intensity of the changes promoted by the Lula administration allows us to say that effective reforms were implemented and produced radical changes. They represented a turning point in the history of social assistance policy, especially in view of the lack of significance of previous regulations. The question that now comes up is, why were the actions under Cardoso restrictive regarding social assistance policy and under Lula they were not? There is no denying the innovations brought about by Fernando Henrique Cardoso, such as the Continuous Cash Benefit (BPC), the Child Labor Eradication Program (PETI) and the incipient cash transfer programs. However, the norms lacked significance from the point of view of the construction of the social assistance policy. Cardoso carried out necessary innovative actions based on solidarity, but they only partially complied with what was constitutionally determined and followed a restricted and fragmented agenda. But institutionalized policies were not sufficiently constructed to respond to the principles of universal social protection determined by the Federal Constitution of 1988. There was a different project: certain social rights for specific groups were set up and the idea of a security system based on solidarity entered the specific guidelines of the area during the Cardoso administration. But the social assistance policy was only residual in his political project. 
It was under Lula that social assistance found the political and institutional conditions that allowed for significant changes that have come to redefine the social assistance policy and effectively implement it in the conception of a single decentralized and participatory system, as provided in the first round of reforms when social assistance was assured as a citizen's right. The president had the orientation of his party, now governing the country and facing issues related to social assistance. Thus, he gave this policy weight and significance during his administration, transforming it into a decisive agenda. It was for this purpose that persons who were also committed to this political project were placed at upper levels of this area, especially the minister, and all functioned as important political actors in the process of change.

It can therefore be said that the construction and consolidation of a social protection system called for by the Federal Constitution was only possible from the moment that two factors interacted. On the one hand, the existence of institutional rules that determined the construction of more generous and comprehensive programs, granting rights to the most vulnerable segments of the population and including the principle of solidarity in the system. On the other hand, a more progressive party took over the country, interested in changing the status quo. Also, alternatives for driving the agenda were available and relied on the presence of a broad spectrum of different political groups, including experts, professionals, non-governmental organizations, social movements and other civil society actors. The conditions for making changes were established.

\section{Final considerations}

The analysis of the recent history of Brazilian social assistance policy make it clear that the social protection right set in the 1988 Constitution was crucial to ensure both the institutionalization of this right in the Brazilian State and its construction during the federal administrations that followed. We have tried to show the differences in the initiatives taken at the Federal Executive Branch in regulating this new public policy by pointing out the importance of the ideology of each president's party in determining his own political project, especially his social policy.

Both President Cardoso and President Lula, early in their terms, brought about significant institutional changes in social assistance policy. However, under President Cardoso, changes were heavily marked by the attempt to minimize the actions in this area whereas, in Lula administration, changes were directed to building up a new conception of social protection.

A first aspect of these changes concerns the organizational structure itself, since, at the beginning of each administration, important changes took place involving the 
extinction and creation of ministries, departments and programs, meaning, in both cases, new institutional frameworks for non-contributive social protection. Thus, both the creation of the Ministry of Social Security and Social Service (MPAS) during the Cardoso administration and the creation of the Ministry of Social Assistance (MAS) and the Special Ministry for Food Security and Fight Against Hunger (MESA), and MESA's subsequent merger with the Ministry of Social Development and Combat Against Hunger (MDS) in 2004, became new points of channeling the demands of the social players involved.

However, a second aspect, and certainly the most important, concerns social assistance policy itself and its correspondence to the directions of each administration. As other authors already pointed out(ALMEIDA, 2004; COSTA, 2009; DRAIBE, 2003), it is not possible to identify a continuous social and political project between the Cardoso and the Lula administrations. First, because the decisions and actions taken during the Cardoso administration failed to replace the fragmented and uncoordinated way that social assistance had inherited. This fact is evidenced by the creation of a structure parallel to the Ministry of Social Security and Social Service (MPAS) - the Community Solidarity Program - which clearly took over the government's social agenda at the expense of the Ministry of Social Security and Social Service (MPAS), which, legally had the power and authority to coordinate the policy at the federal level. The National Conferences on social assistance in 1995 and 1997 criticized this situation and proposed the extinction of the program, which the government did not do. Besides, the initiatives for constitutional and legal precepts provided in the Organic Law on Social Assistance were very timid and did not produce significant changes in the organization and operation of a policy system as determined by the norms.

Only after a more progressive administration assumed power could a social agenda clearly take place as a responsibility of the State. It was therefore a point in the government's strategic plan that allowed for a national social assistance policy to be institutionalized, replacing a mere fragmented variety of assistance programs. This policy was strongly based on two pillars, one being conditional cash transfer and other being the structuring of the Unified Social Assistance System. This system introduced significant changes in the relationship among the states and their role within the system, in the form of federal funding, in the organization of social protection, in the role of negotiation levels, agreements, deliberation and participation. In the case of participation, one can affirm that the Lula administration fulfilled a determination that had been taken at the National Conferences on Social Assistance since 1995 and that was evident again in 2003, namely, the implementation of the Unified Social Assistance System.

It is this distinction between the two administrations that this article points out. There were substantial differences in the governmental programs of the two administrations in 
regard to social issues and they can be seen as well in their political projects. This allows us to say that it was the presence of a more progressive party in power that enabled the institutionalization of new policies, since political groups, specifically, the policy community had their capacity to act enhanced.

Finally, a finding of this paper is the importance of the backing for the rules of the game from other factors. The study strongly suggests that the action of the administrations analyzed was based on constitutional provisions and their subsequent regulations, but they alone did not determine the final result. The introduction of new rules constrained the government's choices regardless of specific orientations or fiscal pressures. This became a protective barrier against the action of the conservative Collor administration, for instance. The Cardoso administration only partially fulfilled the legal provisions, as it inserted important aspects of social protection based on national solidarity but failed to structure a policy. It was only the combination of the institutional foundation with more progressive orientations that made it possible to consolidate the National Social Assistance Policy. In other words, it is clear that the first moment of reform, the National Constitutional Assembly, was crucial for the construction of the social assistance policy during these two decades, but the ideological orientations of the parties in government were also decisive for its effective implementation.

Therefore, the explanatory potential of the new structures called for by the Constitution and its regulations occurred in interaction with the arrangement of political forces within each government, either more conservative or more progressive. Constitutional provisions by themselves did not push the social assistance policy when the ideological preferences of the ruling party were more conservative. Instead, its effect was to avoid backslides desired by conservatives in reaction to the new rules, especially regarding the allocation of new funding sources (FAGNANI, 1999). We understand that in politics not to move backwards can be as significant as moving ahead at other times. The constitutional rules allowed the action of external pressure groups to block vetoes imposed by the president. In more conservative administrations, closer to the center, as were the Cardoso's, the implementation of programs were clearly determined by the 1988 Constitution, such as the Continuous Cash Benefit. Then, given the preference for fiscal adjustment, the result was mainly lack of action in restructuring the social assistance policy. Finally, a more progressive administration used these new rules to change the status quo, then structuring the social assistance policy toward principles of non-contribution and more comprehensive entitlement that represents the attainment of full citizenship.

Revised by Terêncio E. Hill

Submitted in July 2013

Accepted in March 2014 


\section{References}

ALCHORNE, Sinderly (2013), 20 anos de LOAS: Análise das normativas nacionais. O Social em Questão. Ano XVII, No 30, 22p. Available at http://www.osocialemquestao.ser.puc-rio.br/ media/OSQ_30_Sindely_2.pdf

ALMEIDA, Maria Hermínia T. (2004), A política social no governo Lula. Available at http://www. fflch.usp.br/dcp/assets/docs/MariaHerminia/Lula.pdf. p.18.

BEVERIDGE, Sir William (1943), O Plano Beveridge. Rio de Janeiro: Livraria Editora José Olympio.

BOSCHETTI, Ivanete (2006), Seguridade Social e Trabalho. Paradoxos na construção das Políticas de Previdência e Assistência Social no Brasil. Brasília: Letras Livraria/UnB.

CARDOSO, Fernando Henrique (1994), Mãos à obra, Brasil: proposta de governo. Available at www.centroedelstein.org.br. 136 p. Access in 28/01/2014.

CARDOSO, Fernando Henrique (1998), Avança Brasil: proposta de governo. Available at www. centroedelstein.org.br. 178 p. Access in 28/01/2014.

CARDOSO JÚNIOR, José Celso and JACCOUD, Luciana (2005), Políticas sociais no Brasil: organização, abrangência e tensões da ação do Estado. IN: JACCOUD, Luciana et al. (Org.). Questão social e políticas sociais no Brasil contemporâneo. Brasília: IPEA. p.181-260.

COSTA, Nilson do Rosário(2009), A proteção social no Brasil: universalismo e focalização nos governos FHC e Lula. Ciência \& Saúde Coletiva, vol.14, No3, pp. 693-706.

COUTO, Berenice Rojas; YASBECK, Maria Carmelita; SILVA, Maria Ozanira da Silva and RAICHELIS, Raquel (Orgs.) (2011), O Sistema Único de Assistência Social no Brasil: uma realidade em movimento. São Paulo: Cortez.

CUNHA, Eleonora S. M. (2013), Efetividade deliberativa de conselhos de assistência social. Jundiaí: Paco Editorial.

DRAIBE, Sonia Miriam (1998a), A construção institucional da política brasileira de combate à pobreza: perfis, processos e agenda. IN: REIS VELLOSO, J. P. , Fórum Nacional - O Brasil e o Mundo no limiar do novo século. Rio de Janeiro: Editora José Olympio, pp. 300-328.

DRAIBE, Sonia Miriam (2003), A política social no período FHC e o sistema de proteção social. Tempo social. Vol.15, No 02. São Paulo: USP. November. pp. 64-101.

DYE, Thomas D. (2003), Understanding Public Policy. Englewood Cliffs, N.J.: Prentice-Hall.

ESPING-ANDERSEN, Gøsta (1990), The Three Worlds of Welfare Capitalism. Cambridge: Polity Press.

ESPING-ANDERSEN, Gøsta (1999), Social foundations of postindustrial economies. Princeton: Princeton University.

EVANS, Peter; RUESCHEMEYER, D. and SKOCPOL, Theda (1985), Bringing the State Back In. Cambridge: Cambridge University Press. 
FAGNANI, Eduardo (1999), Ajuste econômico e financiamento da política social brasileira: notas sobre o período recente 1993/1998. Economia e Sociedade, No 13. Campinas: IE/ Unicamp. pp. 155-178.

FAGNANI, Eduardo (2009), Tensão entre paradigmas: notas sobre a política social no Brasil (1988/2008). Ciência e Saúde Coletiva, Vol. 14, No 03, pp.707-719.

FLEURY, Sônia (1994), A montagem do padrão de seguridade social na América Latina: cooptação e regulação. IN: Fleury, Sônia. Estado sem cidadãos. Rio de Janeiro: Fiocruz. pp. 175-196.

GEORGE, Alexander L. and BENNET, Andrew (2005), Process tracing and historical explanation. In: Case studies and theory development in the social sciences. MIT Press, Cambridge, Massachussets.

HAGGARD, Stephan and KAUFMAN, Robert R. (2008), Development, Democracy and Welfare States: Latin America, East Asia, and Eastern Europe. Princeton: Princeton University Press.

HUBER, Evelyne; RAGIN, Charles and STEPHENS, John D. (1993), Social Democracy, Christian Democracy, Constitutional Structure and the Welfare State. American Journal of Sociology, Vol. 99, No. 3, pp. 711-749.

IMMERGUT, E. (1996), As regras do jogo: a lógica da política de saúde na França, na Suíça e na Suécia. Revista Brasileira de Ciências Sociais, № 30, pp. 139-165.

IPEA (2007), Boletim de Políticas Sociais - acompanhamento e análise $n^{0} 13$, edição especial. Available at http://www.ipea.gov.br/sites/000/2/publicacoes/bpsociais/bps_13/BPS_13_ completo.pdf. 377 p. Access in 28/01/2014.

IPEA (2009), Boletim de Políticas Sociais - acompanhamento e análise $n^{0} 17$, edição especial. . Available at http://www.ipea.gov.br/sites/000/2/publicacoes/bpsociais/bps_17/BPS_17_ completo.pdf. 280p. Access in 28/01/2014.

KING, Gary; KEOHANE Robert O. and VERBA, Sidney (1994), Designing Social Inquiry: Scientific Inference in Qualitative Research. Princeton: Princeton University Press.

KINGDON, John W. (2003), Agendas, alternatives, and public policies. New York: HarperCollins.

KORPI, Walter (1983), The democratic class struggle. London: Routledge.

LAVINAS, Lena(1998), Programas de garantia de renda mínima: Perspectivas brasileiras. Brasília: Rio de Janeiro: IPEA. (texto para discussão n 596). 42 p.

LOWI, Theodor (1964), American Business, Public Policy, Case Studies and Political Theory. World Politics, Vol. 16, No. 4, pp. 677-715.

LOWI, Theodor (1972), Four Systems of Policy, Politics, and Choice. Public Administration Review, Vol. 32, pp. 298-310.

MAHONEY, James (2012), The Logic of Process Tracing Tests in the Social Science. Sociological Methods \& Research. Vol. XX (X), pp. 1-28. SAGE Publications. Available at http://www. sagepublications.com. Access in 28/01/2014. 
MENICUCCI, Telma (2007), A implantação da reforma sanitária: a formação de uma política. IN: HOCHMAN, Gilberto; ARRETCHE, Marta and MARQUES, Eduardo (Org.). Politicas públicas no Brasil. Rio de Janeiro: Ed. Fiocruz. pp. 303-325.

MINISTÉRIO das Relações Exteriores (2008), Brasil. Presidente (1985-1990: José Sarney). Discursos selecionados do Presidente José Sarney. Brasília: Fundação Alexandre de Gusmão. Available at www.funag.gov.br/bilioteca/dmdocuments/0510.pdf

MINISTÉRIO do Desenvolvimento Social e Combate à Fome (MDS) (2004), Política Nacional de Assistência Social: PNAS. Brasília. 59 p. Available at http://www.mds.gov.br/backup/ arquivos/pnas_final.pdf. Access in 28/01/2014.

MINISTÉRIO do Desenvolvimento Social e Combate à Fome (MDS) (2005), Norma Operacional Básica: NOB/Suas. Brasília. Available at <www.servicosocial.ufsc.br/ferramentas/ ferramentas/upload/arquivos/d/nov_versao_final.pdf > . Acesso em 28/01/2014.

MINISTÉRIO do Planejamento, Orçamento e Gestão(2003), Plano Brasil de Todos: Participação e Inclusão - Orientação Estratégica de Governo: Crescimento Sustentável, Emprego e Inclusão Social. Maio. Available at http://www.sigplan.gov.br/arquivos/ portalppa/15_\%28PlanoBrasildeTodos\%29.pdf

MINISTÉRIO Público do Estado do Espírito Santo(2000), Histórico da política de assistência social. (Texto produzido para a Capacitação Regional de Conselheiros Estaduais e Municipais de Assistência Social. Agosto). Available at http://www.mpes.gov.br/anexos/centros_apoio/ arquivos/11_2094171243852009_1_1_historico_politico_assistencia_social.pdf 8 p.

NICOLAU, J. M. (1998), Dados eleitorais do Brasil: 1982-1996. Rio de Janeiro: Revan, IUPERJUCAM.

NÚCLEO DE SEGURIDADE E ASSISTÊNCIA SOCIAL (1994), Mínimos de Cidadania: ações afirmativas de enfrentamento à exclusão social. São Paulo: PUC-SP.

NÚCLEO DE SEGURIDADE E ASSISTÊNCIA SOCIAL (1996), Seminário Internacional: Renda Mínima e Exclusão. São Paulo: PUC-SP. 78 p.

OLIVEIRA, Jaime A. de Araújo and TEIXEIRA, S.M.F. (1986), Previdência social - 60 anos de história da previdência no Brasil. Rio de Janeiro: Ed. Vozes.

OLSEN, Johan P. (1997), Institutional Design in Democratic Contexts. The Journal of Political Philosophy. Vol. 05, No 03, p. 203-229.

PINHEIRO, Marcia M. B.(2008), O CNAS: Entre o interesse público e o privado. Phd Thesis, Pontifícia Universidade Católica de São Paulo, São Paulo.

PARTIDO DOS TRABALHADORES (2014), Programas de Governo - Available at http://csbh. fpabramo.org.br/o-quefazemos/memoria-e-historia/documentos-historicos/programas-degoverno-pt Access in 28/01/2014.

PARTIDO DOS TRABALHADORES(2014), Programas de Governo. Available at http://csbh. fpabramo.org.br/node/5881. Access in 28/04/2014.

SANTOS, Wanderley Guilherme (1979), Cidadania e Justiça. A política social na Ordem Pública Brasileira. Rio de Janeiro: Campus. 
SÁTYRO, Natália (2010), Proteção Social no Brasil. Rio de Janeiro: FGV, (Verbete de Dicionário).

SKOCPOL, T. and AMENTA, E. (1986), States and social policies. Annual Review of Sociology. Vol. 12, pp. 131-157.

SKOCPOL, Theda (1995), Protecting soldiers and mothers: the political origins of social policy in the United States. Cambridge: Harvard University Press. 714 p.

SPOSATI, Aldaíza (ed.) (1996), Mínimos de Cidadania Ações Afirmativas de Enfrentamento à Exclusão Social. Caderno do Núcleo de Seguridade e Assistência Social da PUC/SP, No 4.

SPOSATI, Aldaíza (2003a), Assistência na trajetória das políticas sociais brasileiras: uma questão em análise, 8 aed. São Paulo: Cortez. 160 p.

SPOSATI, Aldaíza (2003b), A Menina LOAS. Lecture at the Opening of the IV Conferencia Nacional de Assistência Social. Available at http://www.ebah.com.br/content/ABAAAAM1QAH/ menina-loas. Access in 28/01/2014.

TESSAROLO, Enzo Mayer and KROHLING, Aloísio (2011), A Passagem do Programa Comunidade Solidária para o Programa Bolsa Família: continuidades e rupturas. CAOS. Revista Eletrônica de Ciências Sociais, No 16, pp. 74-92.

VALENTE, F.L.S. (2004) A política de insegurança alimentar e nutricional no Brasil de 1995 a 2002. Available at http://www.fomezero.gov.br/download/pol_inseg_alimentar_Flavio Valente.pdf Access in 28/01/2014. 